\title{
Research on Business Risk Management for Small and Medium Commercial Banks
}

\author{
Dan Cui \\ Business administration school, Dalian Vocational\&technical College, Dalian Liaoning 116035, \\ China
}

1471378931@qq.com

Keywords: Financial Market Operations; Risk Management; Small and Medium-sized Banks.

\begin{abstract}
With the continuous deepening of financial reform and financial innovation, the mode of China's financial industry as a separate operation has been challenged. Under this background, on the one hand, the competition between commercial banks is becoming increasingly fierce. On the other hand, regulatory authorities are stricter in the supervision of traditional credit businesses. The profit space of the traditional loan business model is limited. The emerging financial markets, represented by funds, bonds and financial services, have become increasingly flourishing and become a new source of profit for commercial banks. According to the characteristics of the commercial banking business in the financial market and the development status of the financial market business of the commercial banks in China, the opportunities and challenges for the commercial banks to develop their financial markets business are elaborated. Then, the history and status quo of the market business development of China's small and medium-sized commercial banks are analyzed. Combined with the actual case, the strategy of business risk management of financial markets in small and medium-sized banks is discussed.
\end{abstract}

\section{Introduction}

Since the 21 st century, with the globalization of international financial markets and the continuous deepening of China's financial system reform and innovation, commercial banks have accelerated their financial market operations [1,2]. The professional financial market business unit was established. In recent years, the scale and revenue of all commercial banks in the financial market have risen steadily. In the balance sheet of commercial banks, its scale is increasing. Its business unit has become a center of capital operation, asset and liability management, financial product innovation platform and new profit creation center for major banks from the traditional fund transfer function. However, the emerging financial market business has brought tremendous business risks to commercial banks while generating huge profits [3]. In particular, some small and medium-sized commercial banks and rural credit unions that have just been restructured failed to timely support and establish corresponding risk management mechanisms while rapidly developing their business in the financial markets, so that they have suffered huge losses in the course of bank operations and management. Starting from the development characteristics of small and medium bank financial market business, its uniqueness has been studied. Based on the theory of financial market risk management and combining with the case, the risk management of financial market business development in small and medium-sized banks is studied. The risk management solutions that are in line with the characteristics of small and medium-sized banks are explored [4].

\section{An Overview of the Financial Market Business and its Risks in Commercial Banks}

\subsection{An Overview of the Financial Market Business}

The financial market is the sum of the supply and demand and its mechanism based on the financial assets. It contains the following three levels of connotation [5]. First, financial market is a tangible or intangible place for financial assets to be traded. It refers to the market of funds that are supplied by 
both the capital providers and the demand sides through credit instruments. Secondly, the financial market reflects the supply and demand relationship of financial asset transactions. Finally, the financial market reflects the operation mechanism of a series of financial extensive transactions including price mechanism. According to the trading term, finance can be divided into money market (short term financial market, trading term is less than a year) and capital market (also known as long term financial market, and the trading term is more than one year). According to the different transaction procedures, finance can be divided into the issuance market (also known as the primary market) and the circulation market (also known as the secondary market). According to the transaction delivery time, finance can be divided into spot market and futures market. According to the subject matter of different transactions, finance can be divided into money market, foreign exchange market, capital market and gold market. The participants in the financial market, that is, the buyers and sellers participating in the transaction of financial assets, include the government, the business enterprise, the financial institution and the individual. A financial instrument, which is produced in a financial transaction, is an effective document that can prove the elements of the transaction.

In a broad sense, the financial market business of commercial banks includes both investment banking activities such as listing and promotion of securities companies, securities underwriting and brokerage, and financial matters, as well as liquidation of securities trading and fund transfer of bank-cards provided for the operation of financial markets and market investors. These businesses are the financial needs of commercial banks around the various financial entities of the financial market, and are important means to expand the traditional business areas and enhance the level of financial services on the basis of promoting cooperation on the same industry. In a narrow sense, the commercial banking business in the financial market can be divided into the following categories. The first category is the financial market clearing and agency business, which mainly includes clearing and settlement services for the securities market, brokerage and retail brokerage business, and brokerage account, and fund custody, retail and consignment business. The second category provides financing services for securities firms and listed companies. It mainly includes the financing of short-term funds for securities companies, the provision of bridge loans for listed companies and stock pledge loans. The fourth category is the business of self-employed financial markets, including the underwriting and selling of bonds, stocks, trading, transfer and the sale, management, sale and transfer of the fund. The fifth category is the investment banking business of commercial banks. It mainly includes syndicated loan, project financing, asset securitization, enterprise and project finance and investment, development strategy consultant, enterprise capital trusteeship, factoring business, personal investor financial management and investment consultant. The above categories are the usual financial market business of commercial banks in the world. Among them, the first and second categories are settlement and agency financial market businesses, which belong to the marginal financial market business of commercial banks. It provides services for the financial market by traditional business advantages. The third to fifth category belong to the core financial market business. In short, the commercial banking business in the financial market is a product of the commercial banks being forced to adjust their service functions, business directions and competitive strategies in the increasingly fierce competition. Through the combination of financial products and financial services, commercial banks become important players in financial markets. The business model, which traditionally takes risky spreads through deposit and loan businesses, is converted to intermediary service fees that are risk-free or low-risk through financial intermediation services. Most mature commercial banks in developed countries are moving in the same direction.

\subsection{The Current Situation and Characteristics of the Financial Market Business of Commercial Banks in China}

In the early stage of reform and opening up, several major state-owned banks set up securities, trusts, leasing, real estate and investment [6]. The financial industry is essentially in a mixed operation period. In 1995, the system of separate operation of the financial system was formally established from the law. By 2003, China's financial industry separation regulatory system has initially been 
completed. Separation regulation has enhanced the specialization of financial supervision, reduced financial risks, enhanced the strength of regulatory bodies and reduced the occurrence of systemic risks. At the same time, it also enhances the effectiveness of monetary policy and inhibits over speculation. However, with the ever-changing economic and financial situation, especially under the background of the rapid development of the financial industry, the disadvantages of the separate operation gradually appear. On the one hand, under the system of separate operation, the bank's participation in the securities business is limited and does not have the function of transfer risk and hedging. On the other hand, under the restriction of separate operation, the banking financial innovation is greatly inhibited. With the continuous development of the financial reform and the continuous exploration of financial innovation, the financial market business has emerged as the emerging business of commercial banks. Generally speaking, the financial market business of commercial banks bears the important responsibilities of commercial banks in asset management, capital operation and diversified financial services for customers. The financial market department of commercial banks mainly undertake various functions of commercial banks, such as currency or foreign currency, financial market related transactions, investment and risk management, research and other functions. The unified trading platform covering the local currency and the foreign currency market has been built [7]. The competitiveness and service level of the financial market will be promoted in an all-round way. Its business scope involves foreign currency, capital transactions, foreign exchange transactions, derivatives trading, bond investment, precious metals trading, commodity futures trading, financial services and other fields. It plays an important role in promoting the comprehensive competitiveness of commercial banks. The change of the yield curve of the interbank market in 2015 is shown in Figure 1.

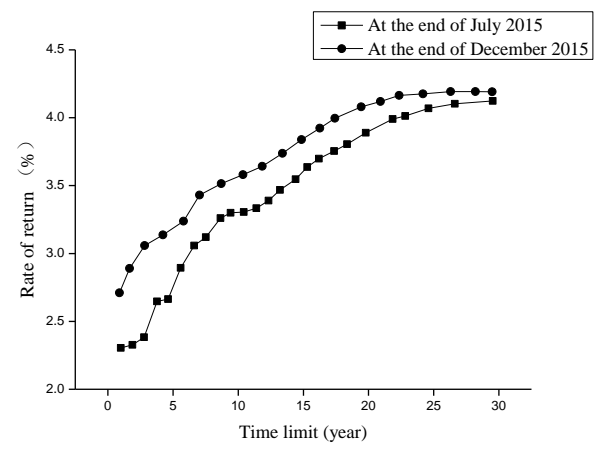

Figure 1. The change of the yield curve of the interbank market in 2015

\section{Case Analysis}

\subsection{Analysis on the Current Situation of X Banking Financial Market}

Banks are a group of earlier financial institutions that joined the interbank market. It has a number of eligibility on the open market primary traders, the financial underwriting syndicate of the three major policy banks (China Development Bank, China Export-Import Bank, China Agricultural Development Bank), the qualifications of the State Treasury cash deposit bank and the clearing agency qualifications. In 2012, the settlement of funds business was 807.003 billion yuan. Various types of bonds are 30,085 million yuan, investment income is 260 million yuan. The end of the year bond investment balance is 105.29 billion yuan. Its business scope covers bonds, money market, notes business, forex parent and so on. X bank, as a commercial bank based on traditional business, has gradually established a set of more perfect enterprise credit system for many years. The X bank has formulated the annual credit policy through the credit rating scale of the small enterprise legal person. In the authorization management, collateral management, group customer credit management, guarantee company management, consumer financial credit management, small business credit management, loan management, early warning management, credit management and so on, a sound credit management system was established. In terms of system support, the first and second phases of 
the new generation of credit management system have also been completed. For the rapid development of the financial market business, it has not yet established a supporting credit management system. However, the business model of the financial market is more complex than the traditional loan business, and the target variety of the investment and the scope of the debt subject are wider and more diverse. The risk of interest rate repricing is shown in Table 1 . The date is December 31, 2012. Unit: ten thousand yuan.

Table 1. The risk of interest rate repricing

\begin{tabular}{|c|c|c|c|c|c|c|c|}
\hline Project & Total & 1 month & $\begin{array}{c}1 \text { to } 3 \\
\text { months }\end{array}$ & $\begin{array}{c}3 \text { to } 6 \\
\text { months }\end{array}$ & $\begin{array}{c}6 \text { months to } \\
1 \text { year }\end{array}$ & $\begin{array}{c}1 \text { to } 3 \\
\text { years }\end{array}$ & $\begin{array}{c}\text { Over 3 } \\
\text { years }\end{array}$ \\
\hline $\begin{array}{c}\text { Various loans of the } \\
\text { domestic currency }\end{array}$ & 1275018 & 148743 & 722441 & 224012 & 167291 & 12421 & 110 \\
\hline $\begin{array}{c}\text { Various loans of the } \\
\text { dollar }\end{array}$ & 36182 & 15060 & 7564 & 0 & 13558 & 0 & 0 \\
\hline Total Loans & 1311200 & 163803 & 730005 & 224012 & 180849 & 12421 & 110 \\
\hline Dollar deposit & 4467049 & 3088850 & 200665 & 248820 & 232395 & 123968 & 572352 \\
\hline Local currency deposit & 51551 & 49468 & 1856 & 136 & 88 & 3 & 0 \\
\hline Total deposits & 4518600 & 3138318 & 202520 & 248956 & 232483 & 123971 & 572352 \\
\hline $\begin{array}{c}\text { Interest rate sensitivity } \\
\text { gap }\end{array}$ & -3207400 & -2974515 & 527485 & -24943 & -51634 & -111550 & -572242 \\
\hline $\begin{array}{c}\text { The time weight of net } \\
\text { interest income in one } \\
\text { year }(\%)\end{array}$ & & $1.92 \%$ & $1.67 \%$ & $1.25 \%$ & $0.50 \%$ & -258 & \\
\hline $\begin{array}{c}\text { The effect of } 200 \text { basis } \\
\text { points on net interest } \\
\text { income rising }\end{array}$ & -48872 & -57111 & 8809 & -312 & -2523608 & -2635158 & -3207040 \\
\hline $\begin{array}{c}\text { Total interest rate } \\
\text { sensitivity gap }\end{array}$ & & -2974515 & -2447030 & -2471974 & -250 & \\
\hline
\end{tabular}

\subsection{Suggestions on Risk Management of Financial Market in Small and Medium Sized Commercial Banks}

The financial market sector should be set up. The operation department of backstage business settlement and accounting treatment, and the professional risk management and monitoring department should be established. The organizational structure of the collaboration and independent checks and balances has been formed. The financial market department is responsible for the operation of specific business and the undertaking of business risk, which is the profit center of the bank. The risk management department should control the overall risk of the financial market business, as well as the profit and loss accounting and identification of the business sector. It is responsible for reporting to the special risk management committee and the executive layer. The operating department is responsible for accounting. The business risk management department and the financial market department should be completely independent. It reports to different executives. In addition, due to the complexity of trading mechanisms and operating procedures in financial markets, the phenomenon of over-authorization still occurs. Traditional regulation has encountered serious challenges. A sound internal risk control mechanism should be established to improve the financial market transaction system.

The importance of market risk prevention in financial market operations has gained widespread acceptance in financial markets. Compared to large banks, small and medium banks have a thin foundation, and the traditional business is shallow. Once the financial market fluctuates greatly, fluctuations in its asset prices may cause it to suffer catastrophic losses. Therefore, more attention should be paid to the management of market risks. First of all, small and medium-sized banks should establish a timely and effective market risk analysis and reporting mechanism, a major market risk response mechanism and a market risk management mechanism for new products and new businesses. In particular, they should strictly distinguish between bank accounts and trading accounts. For different accounts, the corresponding market risk identification, measurement, monitoring and control methods have been developed. Then, depending on their ability, small and medium-sized 
banks can buy and develop specialized market risk management systems. The basic data are all included in a unified market risk management system. On the basis of the curve of the yield of RMB treasury bonds, the daily profit and loss data of the trading account will start to accumulate as early as possible. It is ready to implement an internal model of market risk.

\section{Conclusion}

With the continuous progress of the internationalization of financial markets, the subtle changes in the financial markets at home and abroad will cause a fierce reaction in the financial markets. It has a significant impact on the operations and performance of commercial banks. Traditional commercial banks are the credit intermediaries that regulate the shortage of funds in various social sectors. Its profit is obtained in the process of operating capital surplus value, which is based on credit. The business model of traditional commercial banks and investment banks affects each other. The financial market business of commercial banks came into being and developed rapidly. At the same time, the leverage ratio of commercial banks is increasing. Although the level of profitability has risen rapidly, the potential risks have also been magnified with high leverage. Therefore, commercial banks must strictly control the bottom line of business risk, and pay high attention to the prevention of market risk, so as to achieve steady operation.

\section{References}

[1]. Mehra, Y. S. (2017). Awareness of Risk Management Practices System in Indian Commercial Banks-A Perception based Analysis. Asian Journal of Research in Banking and Finance, 7(5), $1-12$.

[2]. Buyl, T., Boone, C., \& Wade, J. B. (2017). CEO Narcissism, Risk-Taking, and Resilience: An Empirical Analysis in US Commercial Banks. Journal of Management, 0149206317699521.

[3]. Bashir, A., \& Hassan, A. (2017). Interrelationship Among Basel Capital Regulation, Risk, and Efficiency in Pakistani Commercial Banks. Business \& Economic Review, 9(2), 165-186.

[4]. Simper, R., Hall, M. J., Liu, W., Zelenyuk, V., \& Zhou, Z. (2017). How relevant is the choice of risk management control variable to non-parametric bank profit efficiency analysis? The case of South Korean banks. Annals of Operations Research, 250(1), 105-127.

[5]. Tang, Y., Peng, L., \& Zhang, X. (2016). Research on the Contrast and Reference of Commercial Bank Risk Management of International Studies based on the Interest Rate Marketization. DEStech Transactions on Social Science, Education and Human Science, (isetem).

[6]. Ndoka, S., Islami, M., \& Shima, J. (2017). The impact of liquidity risk management on the performance of Albanian Commercial Banks during the period 2005-2015. International Journal of Social Sciences and Education Research, 3(1), 70-76.

[7]. Rahman, M. L., \& Banna, S. H. (2016). Liquidity Risk Management: A Comparative Study between Conventional and Islamic Banks in Bangladesh. Journal of Business and Technology (Dhaka), 10(2), 18-35. 